Original Article

Artigo Original

Nélia de Medeiros Sampaio ${ }^{1}$

Mario Cezar Oliveira ${ }^{1}$

Adriana de Oliveira Ortega ${ }^{2}$

Lydia de Brito Santos $^{1}$

Técia Daltro Borges Alves ${ }^{1}$

Keywords

Temporomandibular Joint Disorders

Prevalence

Elderly

Temporomandibular Joint

Aging

\section{Correspondence address:}

Nélia de Medeiros Sampaio

Universidade Estadual de Feira de

Santana - UEFS

Avenida Universitária, s/n, Feira de

Santana (BA), Brazil, CEP: 44036-900.

E-mail: neliamsampaio@gmail.com

Received: June 07, 2016

\title{
Temporomandibular disorders in elderly individuals: the influence of institutionalization and sociodemographic factors
}

\begin{abstract}
Purpose: The aim of this study was to determine the factors associated with temporomandibular disorders (TMD) in the non-institutionalized and institutionalized elderly population of Feira de Santana, Bahia, Brazil. Methods: A cross-sectional study was carried out in 307 subjects over 60 years old of both genders, where 80 are institutionalized and 227 are non-institutionalized. The evaluation of TMD signs and symptoms was performed using the Fonseca Anamnestic Index (IAF) as to sociodemographic, systemic and otological factors. The results were analyzed by correlating the study factors and the prevalence of TMD. A $95 \%$ confidence interval (CI) and a 5\% significance level were established for all the tests used. Results: The results showed that $50.5 \%$ of the subjects presented some degree of TMD. The prevalence of TMD was $49.8 \%$ among non-institutionalized elderly individuals and of 52.5\% among institutionalized individuals. Variation in the prevalence of TMD, with statistical significance according to gender, age, income, tinnitus, dizziness, and depression was observed. Conclusion: The prevalence of TMD was significant among the elderly population. There was no statistically significant difference between the prevalence of TMD in institutionalized and non-institutionalized individuals. Identifying TMD in the elderly population may be difficult because the symptoms of these disorders are similar to symptoms commonly presented in some systemic disorders associated with aging.
\end{abstract}

Study carried out at Programa de Pós-graduação em Saúde Coletiva Feira, Universidade Estadual de Feira de Santana - UEFS - Feira de Santana (BA), Brazil.

${ }^{1}$ Universidade Estadual de Feira de Santana - UEFS - Feira de Santana (BA), Brazil.

${ }^{2}$ Universidade Cruzeiro do Sul - São Paulo (SP), Brazil.

Financial support: nothing to declare.

Conflict of interests: nothing to declare. 


\section{INTRODUCTION}

Temporomandibular disorders (TMD) has been described as a cluster of disorders characterized by pain in the preauricular area, masticatory muscles and temporomandibular joint (TMJ), limitation or deviations in mandibular range of motion, and clicking of the TMJ during mandibular function. The prevalence of this condition varies between 16 and 59\% depending on the type of population studied, as well as on the diagnostic system used. Although not categorized as a public health problem, TMD are becoming important diseases in the healthcare field due to the number of people they affect. Literature reports great variability in the prevalence of clinical symptoms and signs, probably as a result of the different clinical criteria used ${ }^{(1,2)}$.

TMD may be a challenge due to its multifactorial etiology, with characteristics that can mimic many other different conditions. They have behavioral and systemic components and therefore are complex to diagnose. Their clinical manifestations can be acute or chronic, accompanied or not by pain and impaired jaw function ${ }^{(3,4)}$.

The degree of difficulty to diagnose TMD is increased among the elderly population because their symptoms are presented simultaneously with biochemical and physiological alterations related to aging ${ }^{(4)}$. Healthcare professionals need to understand how these changes lead to TMD, and how they affect pre-existing conditions ${ }^{(5)}$. It is important to bear in mind that the elderly may have complications of disease processes accumulated over their lifetime, which could lead to an increased prevalence of TMD in this age group ${ }^{(6,7)}$.

Studies have shown that changes in systemic conditions may vary among the institutionalized and non-institutionalized elderly population ${ }^{(7-9)}$. Thus, this study aimed to identify the association of sociodemographic, systemic and otological factors related to muscle pain with TMD in a non-institutionalized and institutionalized group of elderly people in a semi-arid region in Brazil.

\section{METHODS}

A cross-sectional epidemiological study was conducted in Feira de Santana, state of Bahia, Brazil.

According to the World Health Organization (WHO), in developing countries an elderly person is defined as someone over 60 years old ${ }^{(10)}$. Psychological ability to respond to the survey instrument was used as an inclusion criteria. All residents of Long Term Institutions for the Elderly (NHs) registered in the
Secretary of Social Development of the City of Feira de Santana, and all registered seniors attending the workshop program of the Third Age Open University were considered eligible for this study. Thus, the study population comprised 307 elderly, where 80 were institutionalized (NHs) and 227 non-institutionalized individuals.

For the purpose of calibration for the researchers and adequacy of the instrument, we used a pilot study performed with the participation of 30 individuals who attend a daycare center for the elderly in the city. All participants were re-examined a week later.

After the pilot study, adjustments were made to the instrument designed for the study, which consisted of an epidemiological survey divided into blocks of data comprising the sociodemographic, systemic and otologic factors, as well as muscle pain. The Fonseca Anamnestic Index (IAF) was used to detect TMD ${ }^{(11)}$. The IAF was chosen because it is available in Portuguese; it's a valid tool for characterization of TMD symptoms; it's recommended for use in the public health service for screening of TMD; and due to its simplicity, rapidity and low $\cos ^{(11-14)}$.

The index consists of 10 questions that can be answered with "Yes", "Sometimes" and "No", associated with scores 10 (ten), 5 (five) and 0 (zero), respectively. The sum of these scores categorized TMD as: absent, if the score was below 20; and present, if the score was above 20. Where TMD was present, it was classified as: mild, if the score was below 45; moderate, if the score was below 70; and severe, if the score was above $70^{(11-14)}$.

The data collected was statistically analyzed using the program R version 2.9.0 (Vienna, Austria). In order to evaluate the association between the study factors, prevalence of TMD and prevalence rates, the chi-squared test $\left(\chi^{2}\right)$ was used with a $95 \%$ confidence interval and a 5\% significance level.

The study was submitted to the Research Ethics Committee of Universidade Estadual de Feira de Santana and it was approved under the Kyoto Protocol In 0005/2010, CAEE 0006.0.059.000-10. All individuals who agreed to participate voluntarily in the study were informed of the purposes of the study and signed a consent form.

\section{RESULTS}

The prevalence of TMD was 50.5\% among 307 elderly participants; where $49.8 \%$ of those were non-institutionalized and $52.5 \%$ were institutionalized individuals. There was no significant difference between the two groups (Table 1).

Table 1. Prevalence (\%) of TMD, according to the Fonseca Anamnestic Index (IAF), prevalence ratio (PR) with confidence interval (Cl) of $95 \%$ and p-value of Chi-squared $\left(\chi^{2}\right)$ in non-institutionalized and institutionalized elderly individuals

\begin{tabular}{|c|c|c|c|c|c|c|c|c|}
\hline \multirow{2}{*}{ TMD } & \multicolumn{2}{|c|}{ Total } & \multicolumn{2}{|c|}{ Non-institutionalized } & \multicolumn{2}{|c|}{ Institutionalized } & \multirow{2}{*}{$\begin{array}{c}\text { PR } \\
\left(\mathrm{Cl}_{95 \%}\right)\end{array}$} & \multirow{2}{*}{$\begin{array}{c}\chi^{2} \\
\mathbf{p} \text { value }\end{array}$} \\
\hline & $\mathrm{N}(307)$ & $\%$ & N (227) & $\%$ & $N(80)$ & $\%$ & & \\
\hline Absent & 152 & 49.5 & 114 & 50.2 & 38 & 47.5 & 1 & \multirow{5}{*}{0.676} \\
\hline Present & 155 & 50.5 & 113 & 49.8 & 42 & 52.5 & $1.02(0.90-1.17)$ & \\
\hline Mild & 113 & 72.9 & 76 & 67.2 & 37 & 88.1 & & \\
\hline Moderate & 34 & 21.9 & 31 & 27.5 & 03 & 07.1 & & \\
\hline Severe & 08 & 05.2 & 06 & 02.3 & 02 & 04.8 & & \\
\hline
\end{tabular}


We observed a higher prevalence of TMD among female individuals in the non-institutionalized elderly population of 2.48 (95\% CI: 1.03 to 6.00 ) times that of male individuals, whereas there was no significant differences between the prevalence of TMD in the non-institutionalized population. With regard to age, those between 60 and 70 years old presented the highest prevalence (59.5\%) among the non-institutionalized group, 1.63 (95\% CI: 1.18 to 2.24 ) times higher than the group between 71 and 80 years old. Among institutionalized individuals, the highest prevalence was $57.7 \%$ for the ones between 71 and 80 years old (Table 2).

It was observed that TMD was more prevalent among those individuals with income between $\$ 501.00$ and 1500.00 dollars/month. Among the non-institutionalized elderly, a reduction in prevalence of 0.49 (95\% CI: 0.42 to 0.57 ) times for the lower income group was observed, and among the institutionalized, a reduction of 0.52 (95\%: 0.39 to 0.68 ) times compared to lower and higher income groups (Table 2).

The non-institutionalized elderly population with elementary education level had the highest prevalence of TMD $(62.7 \%$; Table 2).

There was a higher prevalence of TMD among those who reported tinnitus. In the non-institutionalized elderly population, a prevalence 2.28 times higher than those who do not report tinnitus was observed. For institutionalized subjects, the prevalence of
TMD among those with depression was $72.2 \%$, representing an increase of 1.64 (95\% CI: 1.07 to 2.50$)$ times compared to those with no depression (Table 3 ).

Individuals who reported hypertension did not present statistical differences between the prevalence of TMD for both groups studied. The same is true for diabetes and daily use of medication (Table 3).

Prevalence of TMD was greater among older adults who reported pain or tenderness of the muscles involved in mastication. Among those who presented click on TMJ, prevalence of TMD was $66.7 \%$ in non-institutionalized elderly individuals, causing an increase of 1.56 times when compared to the group who did not present click (Table 4).

\section{DISCUSSION}

The prevalence of TMD in non-institutionalized and institutionalized groups presented similar results with no statistically significant difference. In a study performed by Abud et al. ${ }^{(5)}$, the prevalence of TMD was similar for both groups, however with lower prevalence rates (29.5\%).

Some studies have shown that prevalence of TMD in elderly populations is rare ${ }^{(15-17)}$. However, other authors reported that the elderly can often suffer from TMD, but do not complain because they are more concerned with other overall health

Table 2. Prevalence (\%) of TMD according to sociodemographic factors among non-institutionalized and institutionalized elderly individuals and their prevalence ratios (PR) with confidence interval $(\mathrm{Cl})$ of $95 \%$ and $p$-values for Chi-square $(\chi 2)$ test

\begin{tabular}{|c|c|c|c|c|c|c|c|c|}
\hline \multirow{2}{*}{ Variable } & \multicolumn{4}{|c|}{ Non-institutionalized } & \multicolumn{4}{|c|}{ institutionalized } \\
\hline & $\mathbf{N}$ & $\%$ & PR (IC $\left.{ }_{95 \%}\right)$ & $\chi^{2}$ & $\mathbf{N}$ & $\%$ & PR (IC $\left.{ }_{95 \%}\right)$ & $\chi^{2}$ \\
\hline $\begin{array}{l}\text { Gender } \\
\text { Female } \\
\text { Male }\end{array}$ & $\begin{array}{c}109 \\
04\end{array}$ & $\begin{array}{l}52.4 \\
21.0\end{array}$ & $\begin{array}{c}1 \\
2.48(1.03-6.00)^{\star}\end{array}$ & 0.009 & $\begin{array}{l}28 \\
14\end{array}$ & $\begin{array}{l}52.8 \\
51.8\end{array}$ & $\begin{array}{c}1 \\
1.01(0.65-1.58)\end{array}$ & 0.934 \\
\hline $\begin{array}{l}\text { Race } \\
\text { White } \\
\text { Black } \\
\text { Mixed }\end{array}$ & $\begin{array}{l}21 \\
25 \\
67\end{array}$ & $\begin{array}{l}45.6 \\
58.1 \\
48.5\end{array}$ & $\begin{array}{c}1 \\
0.78(0.52-1.17) \\
0.94(0.65-1.34)\end{array}$ & $\begin{array}{c}- \\
0.239 \\
0.733\end{array}$ & $\begin{array}{l}08 \\
06 \\
27\end{array}$ & $\begin{array}{l}47.0 \\
54.5 \\
54.0\end{array}$ & $\begin{array}{c}1 \\
0.86(0.41-1.80) \\
0.87(0.49-1.53)\end{array}$ & $\begin{array}{l}- \\
0.699 \\
0.620\end{array}$ \\
\hline $\begin{array}{l}\text { Age } \\
60 \text { to } 70 \\
71 \text { to } 80 \\
\text { Above } 81\end{array}$ & $\begin{array}{l}75 \\
30 \\
08\end{array}$ & $\begin{array}{l}59.5 \\
36.6 \\
42.1\end{array}$ & $\begin{array}{c}1 \\
1.63(1.18-2.24)^{*} \\
1.41(0.82-2.44)\end{array}$ & $\begin{array}{c}- \\
0.001 \\
0.152\end{array}$ & $\begin{array}{l}08 \\
15 \\
09\end{array}$ & $\begin{array}{l}40.0 \\
57.7 \\
47.3\end{array}$ & $\begin{array}{c}1 \\
0.69(0.36-1.30) \\
0.84(0.41-1.72)\end{array}$ & $\begin{array}{c}- \\
0.234 \\
0.642\end{array}$ \\
\hline $\begin{array}{l}\text { Marital Status } \\
\text { Single } \\
\text { Married } \\
\text { Widower }\end{array}$ & $\begin{array}{l}31 \\
34 \\
47\end{array}$ & $\begin{array}{l}54.3 \\
54.8 \\
44.3\end{array}$ & $\begin{array}{c}1 \\
0.99(0.71-1.37) \\
1.22(0.89-1.69)\end{array}$ & $\begin{array}{c}- \\
0.960 \\
0.220\end{array}$ & $\begin{array}{l}26 \\
04 \\
12\end{array}$ & $\begin{array}{l}56.5 \\
44.4 \\
48.0\end{array}$ & $\begin{array}{c}1 \\
1.27(0.58-2.75) \\
1.17(0.72-1.90)\end{array}$ & $\begin{array}{l}- \\
0.505 \\
0.491\end{array}$ \\
\hline $\begin{array}{l}\text { Educational Level } \\
\text { Illiterate } \\
\text { Incom Elem I } \\
\text { Comp Elem I } \\
\text { Incom Elem II } \\
\text { Comp Elem II } \\
\text { Incom HS } \\
\text { Comp HS } \\
\text { Incom Higher Ed } \\
\text { Comp Higher Ed }\end{array}$ & $\begin{array}{l}01 \\
32 \\
15 \\
21 \\
09 \\
02 \\
27 \\
03 \\
03\end{array}$ & $\begin{array}{l}50.0 \\
62.7 \\
53.5 \\
44.7 \\
50.0 \\
40.0 \\
43.5 \\
60.0 \\
33.3\end{array}$ & $\begin{array}{c}0.87(0.21-3.58) \\
0.69(0.48-0.98)^{\star} \\
0.81(0.52-1.27) \\
0.97(0.63-1.49) \\
0.87(0.50-1.49) \\
1.08(0.35-3.30) \\
1 \\
0.72(0.33-1.56) \\
1.30(0.49-3.43)\end{array}$ & $\begin{array}{l}0.856 \\
0.042 \\
0.377 \\
0.906 \\
0.628 \\
0.877 \\
- \\
0.476 \\
0.562\end{array}$ & $\begin{array}{l}21 \\
07 \\
03 \\
05 \\
01 \\
00 \\
01 \\
01 \\
00\end{array}$ & $\begin{array}{r}58.3 \\
41.2 \\
50.0 \\
71.4 \\
20.0 \\
0.0 \\
33.3 \\
100 \\
0.0\end{array}$ & $\begin{array}{c}1 \\
1.41(0.75-2.66) \\
1.16(0.50-2.71) \\
0.81(0.47-1.40) \\
2.91(0.49-7.20) \\
\inf \\
1.75(0.34-8.87) \\
0.58(0.44-.76)^{*} \\
\text { inf }\end{array}$ & $\begin{array}{l}- \\
0.242 \\
0.702 \\
0.516 \\
0.107 \\
0.245 \\
0.401 \\
0.042 \\
0.245\end{array}$ \\
\hline $\begin{array}{l}\text { Income } \\
\quad<500 \\
501 \text { to } 1.500 \\
1.501 \text { to } 2.500 \\
>2.500\end{array}$ & $\begin{array}{l}02 \\
83 \\
08 \\
02\end{array}$ & $\begin{array}{r}100.0 \\
49.1 \\
34.7 \\
20.0\end{array}$ & $\begin{array}{c}0.49(0.42-0.57)^{\star} \\
1 \\
1.41(0.79-2.52) \\
2.45(0.70-8.56)\end{array}$ & $\begin{array}{c}0.152 \\
- \\
0.196 \\
0.073\end{array}$ & $\begin{array}{l}01 \\
25 \\
00 \\
01\end{array}$ & $\begin{array}{r}100.0 \\
52.0 \\
0.0 \\
100\end{array}$ & $\begin{array}{c}0.52(0.39-0.68)^{\star} \\
1 \\
- \\
0.52(0.39-0.68)^{\star}\end{array}$ & $\begin{array}{c}0.342 \\
- \\
0.302 \\
0.342\end{array}$ \\
\hline
\end{tabular}

\footnotetext{
* Statistically significant at level of $5 \%$
} 
Table 3. Prevalence (\%) of TMD, according to otologic and systemic factors in non-institutionalized and institutionalized elderly, and their prevalence ratios (PR) with confidence interval $(\mathrm{Cl})$ of $95 \%$ and $p$-values for Chi-square test $\left(\chi^{2}\right)$

\begin{tabular}{|c|c|c|c|c|c|c|c|c|}
\hline \multirow{2}{*}{ Variable } & \multicolumn{4}{|c|}{ Non-institutionalized } & \multicolumn{4}{|c|}{ Institutionalized } \\
\hline & $\mathbf{N}$ & $\%$ & PR (IC $\left.{ }_{95 \%}\right)$ & $\chi^{2}$ & $\mathbf{N}$ & $\%$ & PR (IC $\left.{ }_{95 \%}\right)$ & $\chi^{2}$ \\
\hline \multicolumn{9}{|l|}{ Tinnitus } \\
\hline Yes & 87 & 64.4 & 1 & & 28 & 71.8 & 1 & - \\
\hline No & 26 & 28.2 & $2.28(1.60-3.23)^{\star}$ & $<0.001$ & 13 & 32.5 & $2.21(1.35-3.59)^{*}$ & $<0.001$ \\
\hline \multicolumn{9}{|l|}{ Dizziness } \\
\hline Yes & 78 & 68.4 & 1 & & 30 & 73.1 & 1 & - \\
\hline No & 35 & 30.9 & $2.20(1.63-2.99)^{\star}$ & $<0.001$ & 12 & 30.7 & $2.37(1.43-3.94)^{*}$ & $<0.001$ \\
\hline \multicolumn{9}{|l|}{ Hypertension } \\
\hline Yes & 70 & 51.5 & 1 & 0.533 & 17 & 65.3 & 1 & - \\
\hline No & 43 & 47.2 & $1.09(0.83-1.42)$ & & 19 & 41.3 & $1.58(1.01-2.46)$ & 0.049 \\
\hline Diabetes & & & & - & & & & \\
\hline Yes & 20 & 46.5 & 1 & 0.657 & 10 & 55.6 & 1 & - \\
\hline No & 92 & 50.2 & $0.92(0.65-1.31)$ & & 25 & 48.0 & $1.16(0.70-1.91)$ & 0.584 \\
\hline \multicolumn{9}{|l|}{ Depression } \\
\hline Yes & 43 & 67.2 & 1 & - & 13 & 72.2 & 1 & - \\
\hline No & 68 & 42.7 & $1.57(1.22-2.01)^{\star}$ & $<0.001$ & 22 & 44.0 & $1.64(1.07-2.50)^{*}$ & 0.040 \\
\hline \multicolumn{9}{|c|}{ Use of daily medication } \\
\hline Yes & 84 & 48.3 & 1 & - & 32 & 58.2 & 1 & - \\
\hline No & 29 & 54.7 & $0.88(0.66-1.17)$ & 0.412 & 10 & 40.0 & $1.45(0.85-2.47)$ & 0.131 \\
\hline \multicolumn{9}{|l|}{ Indication? } \\
\hline Circulatory & 67 & 49.2 & 1 & - & 13 & 59.0 & 1 & - \\
\hline Bone/articulation & 02 & 40.0 & $1.23(0.41-3.65)$ & 0.684 & 00 & 0.0 & - & - \\
\hline Nervous & 05 & 83.3 & $0.59(0.39-0.87)^{\star}$ & 0.102 & 03 & 33.3 & $1.77(0.66-4.75)$ & 0.192 \\
\hline Endocrine & 03 & 21.4 & $2.29(0.83-6.53)$ & 0.046 & 03 & 75.0 & $0.78(0.40-1.53)$ & 0.547 \\
\hline Others & 07 & 53.8 & $0.91(0.53-1.55)$ & 0.752 & 03 & 60.0 & $0.98(0.44-2.18)$ & 0.970 \\
\hline Do not know & - & - & - & - & 10 & 76.9 & $0.76(0.48-1.21)$ & 0.282 \\
\hline No medication & 29 & 54.7 & $0.90(0.66-1.21)$ & 0.500 & 10 & 38.4 & $1.53(0.84-2.79)$ & 0.154 \\
\hline
\end{tabular}

* Statistically significant values

Table 4. Prevalence (\%) of TMD, according to factors related to muscular hyperfunction and the respective prevalence ratios (PR) with confidence interval $(\mathrm{Cl})$ of $95 \%$ and $p$-values for Chi-square test $(\chi 2)$, in non-institutionalized and institutionalized elderly individuals

\begin{tabular}{|c|c|c|c|c|c|c|c|c|}
\hline \multirow{2}{*}{ Variable } & \multicolumn{4}{|c|}{ Non-institutionalized } & \multicolumn{4}{|c|}{ Institutionalized } \\
\hline & $\mathbf{N}$ & $\%$ & PR (Cl 95\%) & p & $\mathbf{N}$ & $\%$ & PR (Cl 95\%) & p \\
\hline \multicolumn{9}{|l|}{ Temporalis } \\
\hline Yes & 27 & 96.4 & 1 & & 13 & 92.8 & 1 & \\
\hline No & 85 & 43.5 & $2.21(1.85-2.63)^{\star}$ & $<0.001$ & 29 & 43.9 & $2.11(1.55-2.88)^{\star}$ & $<0.001$ \\
\hline \multicolumn{9}{|l|}{ Masseter } \\
\hline Yes & 47 & 74.6 & 1 & & 18 & 78.2 & 1 & \\
\hline No & 65 & 40.6 & $1.83(1.45-2.33)^{*}$ & $<0.001$ & 24 & 42.0 & $1.85(1.28-2.70)^{\star}$ & 0.003 \\
\hline \multicolumn{9}{|l|}{$\begin{array}{l}\text { Sternocleido } \\
\text { mastoid }\end{array}$} \\
\hline Yes & 62 & 82.7 & $2.44(1.90-3.13)^{\star}$ & $<0.001$ & 30 & 46.9 & $1.70(1.18-2.45)^{\star}$ & \\
\hline No & 50 & 33.7 & & & & & & 0.020 \\
\hline \multicolumn{9}{|l|}{ TMJ Clicks } \\
\hline Yes & 38 & 66.7 & 1 & & 08 & 88.9 & 1 & \\
\hline No & 69 & 42.6 & $1.56(1.21-2.02)^{*}$ & 0.002 & 33 & 48.5 & $1.83(1.30-2.56)^{\star}$ & 0.022 \\
\hline
\end{tabular}

* Statistically significant values

issues or more painful and debilitating diseases, leaving aside the symptoms related to the masticatory system ${ }^{(18)}$.

This study showed a high prevalence of TMD in the elderly. Therefore, it is necessary to analyze how diagnosis is generally performed. This condition is often diagnosed by observation of symptoms that are very subjective. Identification of these symptoms depends on cognitive ability, which varies widely both individually and among groups ${ }^{(15-18)}$. According to Schmitter et al. ${ }^{(18)}$, the elderly population presents a higher prevalence of objective signs of TMD; however, they rarely complain of pain.

There was a variation in the prevalence of TMD related to gender, age, educational level and income. Some studies have been reporting that several health problems are associated with social inequalities. These inequalities have been increasing worldwide, as is the elderly population ${ }^{(7,19,20)}$.

Martins et al. ${ }^{(21)}$, in a study performed in São Paulo (Brazil), observed the relationship between occurrence of TMD and economic class, educational level, age and gender, but found a 
statistically significant level for females only. Several studies have showed a higher prevalence of TMD in females. Behavioral, psychosocial, and hormonal differences between male and female individuals have been studied with no conclusive results ${ }^{(3,5,14)}$.

This study found differences in the prevalence of TMD among different educational levels. According to another study ${ }^{(21)}$, education was associated with the acquisition of more information, allowing cognitive assessment of health, which could lead to a different perception of TMD.

A socioeconomic factor that was associated with the prevalence of TMD in this study was monthly rent. Studies report that the poor elderly have worse quality of life related to health ${ }^{(6-9)}$. With regard to income, findings were similar among the groups studied, the elderly who received between one and two minimum wages having the most prevalent TMD rate. Those receiving lower income presented an increase in prevalence of TMD.

Otological factors, such as tinnitus and dizziness, are shown to be associated with the prevalence of TMD in the elderly for both groups studied. An increased prevalence of TMD among the elderly who reported these symptoms was observed. Studies report that tinnitus and dizziness are common in elderly patients $^{(6,7,22-24)}$, as well as in patients with $\mathrm{TMD}^{(25-27)}$.

Depression was a stronger predictor associated with prevalence of TMD. Psychological factors are indicated as etiological for TMD in many studies; however, little is known about the relationship between TMD and neurophysiological etiology of depression ${ }^{(27-29)}$.

The presence of clicks in the TMJ during opening and closing of the mouth was observed with the aid of a stethoscope placed near the external ear. It was noted that among the elderly with clicks the prevalence of TMD was higher than $60 \%$. Although clicks are often present in people with TMD, they cannot be regarded as a diagnostic symptom for these disorders, as they can also be found in individuals who do not suffer from $\mathrm{TMD}^{(30)}$.

It is important to be aware of the limitations of the findings of this study, as they were based on self-reported information. In addition, there was no cognitive assessment test prior to data collection.

\section{CONCLUSION}

This study found a high prevalence of TMD, considering the population studied and the results of other studies. There was no statistically significant association between this prevalence and institutionalization. Gender, age, educational level, income, tinnitus, dizziness, and depression were associated with TMD in the non-institutionalized elderly population. However, in the institutionalized population, only gender was not associated with the presence of TMD.

This study highlights the need for further epidemiological studies to better understand the prevalence of TMD and their systemic, physiological, social and cultural implications for the elderly population. Additionally, it is important to emphasize the need to identify symptoms of TMD in the elderly, particularly those commonly present in some systemic disorders associated with aging.

\section{REFERENCES}

1. Okeson JP. Tratamento das desordens temporomandibulares e oclusão. 5 . ed. São Paulo: Artes Médicas; 2001.

2. Poveda Roda R, Bagan JV, Díaz Fernández JM, Hernández Bazán S, Jiménez Soriano Y. Review of temporomandibular joint pathology. Part I: classification, epidemiology and risk factors. Med Oral Patol Oral Cir Bucal. 2007;12(4):292-8. PMid:17664915.

3. Vilela TT, Siqueira JTT, Siqueira SRDT. Características de dor orofacial em idosos brasileiros freqüentadores de instituição de convivência. Rev Dor. 2009;10(3):236-40.

4. Petersen PE, Yamamoto T. Improving the oral health of older people: the approach of the WHO Global Oral Health Programme. Community Dent Oral Epidemiol. 2005;33(2):81-92. PMid:15725170. http://dx.doi. org/10.1111/j.1600-0528.2004.00219.x.

5. Abud MC, Santos JFF, Cunha VPP, Marchini L. TMD and GOHAI indices of Brazilian institutionalised and community-dwelling elderly. Gerodontology. 2009;26(1):34-9. PMid:18707627. http://dx.doi.org/10.1111/j.17412358.2008.00250.x.

6. Gaszynska E, Szatko F, Godala M, Gaszynski T. Oral health status, dental treatment needs, and barriers to dental care of elderly care home residents in Lodz, Poland. Clin Interv Aging. 2014;25(9):1637-44. PMid:25284997. http://dx.doi.org/10.2147/CIA.S69790.

7. Cornejo M, Pérez G, Lima KC, Casals-Peidro E, Borrell C. Oral healthrelated quality of life in institutionalized elderly in Barcelona (Spain). Med Oral Patol Oral Cir Bucal. 2013;18(2):285-92. PMid:23385501. http:// dx.doi.org/10.4317/medoral.18280.

8. Moreira RS, Nico LS, Tomita NE, Ruiz T. A saúde bucal do idoso brasileiro: revisão sistemática sobre o quadro epidemiológico e acesso aos serviços de saúde bucal. Cad Saude Publica. 2005;21(6):1665-75. PMid:16410850. http://dx.doi.org/10.1590/S0102-311X2005000600013.

9. Morales-Suarez-Varela M, Ibáñez-Cabanell P, Gimeno-Clemente N, Roig-García JM, Nieto-García MA, Llopis-González A. Oral and dental health of non-institutionalized elderly people in Spain. Arch Gerontol Geriatr. 2011;52(4):159-63. PMid:20413167. http://dx.doi.org/10.1016/j. archger.2010.03.007.

10. OMS: Organização Mundial da Saúde, OPAS: Organização Pan-Americana da Saúde. Envelhecimento ativo: uma política de saúde. Brasília: OMS/ OPAS, 2005.

11. Fonseca DM, Bonfante G, Valle AL, Freitas SFT. Diagnóstico pela anamnese da disfunção craniomandibular. Rev Gaucha Odontol. 1994;4(1):23-32.

12. Campos JADB, Gonçalves DAG, Camparis CM, Speciali JG. Confiabilidade de um formulário para diagnóstico da severidade da disfunção temporomandibular. Rev Bras de Fisioterapia. 2009;13(1):38-43. http://dx.doi.org/10.1590/ S1413-35552009005000007.

13. Nomura K, Vitti M, Oliveira AS, Chaves TC, Semprini M, Siessere S, et al. Use of the Fonseca's questionnaire to assess the prevalence and severity of temporomandibular disorders in Brazilian dental undergraduates. Braz Dent J. 2007;18(2):163-7. PMid:17982559. http://dx.doi.org/10.1590/ S0103-64402007000200015.

14. Campos JA, Carrascosa AC, Bonafé FS, Maroco J. Severity of temporomandibular disorders in women: validity and reliability of the Fonseca Anamnestic Index. Braz Oral Res. 2014;28(1):16-21. PMid:25000601. http://dx.doi. org/10.1590/S1806-83242013005000026.

15. Ikebe K, Hazeyama T, Iwase K, Sajima H, Gonda T, Maeda Y, et al. Association of symptomless TMJ sounds with occlusal force and masticatory performance in older adults. J Oral Rehabil. 2008;35(6):317-23. PMid:18405267. http:// dx.doi.org/10.1111/j.1365-2842.2007.01841.x.

16. Almagro CI, Castro SAM, Matarán PGA, Quesada RJM, Guisado BR, Moreno LC. Temporomandibular joint dysfunction, disability and oral health in a community-dwelling elderly population. Nutr Hosp. 2011;26(5):104551. PMid:22072351.

17. Blanco-Hungría A, Rodríguez-Torronteras A, Blanco-Aguilera A, Biedma-Velázquez L, Serrano-del-Rosal R, Segura-Saint-Gerons R, et al. Innfluence of sociodemographic factors upon pain intensity in patients with temporomandibular joint disorders seen in the primary care setting. Med 
Oral Patol Oral Cir Bucal. 2012;17(6):1034-41. PMid:22549669. http:// dx.doi.org/10.4317/medoral.17576.

18. Schmitter M, Rammelsberg P, Hassel A. The prevalence of signs and symptoms of temporomandibular disorders in very old subjects. J Oral Rehabil. 2005;32(4):467-73. PMid:15975125. http://dx.doi.org/10.1111/ j.1365-2842.2005.01449.x.

19. Costa-Lima MF, Matos DL, Camarano AA. Evolução das desigualdades sociais em saúde entre idosos e adultos brasileiros: um estudo baseado na Pesquisa Nacional por amostra de Domicílios. Cien Saude Colet. 2006;11(4):941-52.

20. Dias-da-Costa JS, Galli R, Oliveira EA, Backes V, Vial EA, Canuto $\mathrm{R}$, et al. Prevalência de capacidade mastigatória insatisfatória e fatores associados em idosos brasileiros. Cad Saude Publica. 2010;26(1):79-88. PMid:20209212. http://dx.doi.org/10.1590/S0102-311X2010000100009.

21. Martins RJ, Garcia AR, Garbin CAS, Sundefeld MLMM. The relation between socio-economic class and demographic factors in the occurrence of temporomandibular joint dysfunction. Cien Saude Colet. 2008;13(Suppl 2):208996. PMid:19039392. http://dx.doi.org/10.1590/S1413-81232008000900013.

22. Haesbaert BM, Ferreira GC, Barp G, Grossi ML. Associação entre pressão sanguínea com sinais e sintomas de dor orofacial e disfunção tempormandibular. Revista Odonto Ciência. 2005;20(47):45-9.

23. Felício CM, Faria TG, Silva MAMR, Aquino AMCM, Junqueira CA. Desordem Temporomandibular: relações entre sintomas otológicos e orofaciais. Rev Bras Otorrinolaringol. 2004;70(6):786-93. http://dx.doi. org/10.1590/S0034-72992004000600014.

24. Batista ALA, et al. Avaliação das condições de saúde bucal de idosos institucionalizados no município de Campina Grande - PB. Odontologia Clín-Científ. 2008;7(3):203-8.
25. Lopes MC, Oliveira VMB, Flório FM. Condição bucal, hábitos e necessidade de tratamento em idosos institucionalizados de Araras (SP, Brasil). Cien Saude Colet. 2010;15(6):2949-54. PMid:20922304. http://dx.doi.org/10.1590/ S1413-81232010000600033.

26. Toledo BA, Capote TS, Campos JADB. Associação entre disfunção temporomandibular e depressão. Cienc Odontol Bras. 2008;11(4):75-9.

27. Penna PP, Recupero M, Gil C. Influence of psychopathologies on Craniomandibular Disorders. Braz Dent J. 2009;20(3):226-30. PMid:19784469. http://dx.doi.org/10.1590/S0103-64402009000300010.

28. Giannakopoulos NN, Keller L, Rammelsberg P, Kronmüller KT, Schmitter M. Anxiety and depression in patients with chronic temporomandibular pain and in controls. J Dent. 2010;38(5):369-76. PMid:20079799. http:// dx.doi.org/10.1016/j.jdent.2010.01.003.

29. Plesh O, Adams SH, Gansky SA. Temporomandibular joint and muscle disorder-type pain and comorbid pains in a national US sample. J Orofac Pain. 2011;25(3):190-8. PMid:21837286.

30. Shet RGK, Rao S, Patel R, Suvvati P, Sadar LR, Yadav RD. Prevalence of temporomandibular joint dysfunction and its signs among the partially edentulous patients in a village of North Gujarat. J Contemp Dent Pract. 2013;14(6):1151-5. PMid:24858766. http://dx.doi.org/10.5005/jpjournals-10024-1466.

\section{Author contributions}

NMS is the Lead Researcher of the study, responsible for research, worked on all fronts to carry out the work; $M C O$ is Researcher collaborator in data collection, tabulation and preparation of the article; $A O O$ is Researcher responsible for statistical analysis and article correction; LBS is Collaborating researcher in data collection and correction of the article; TDBA is a Collaborative Researcher in data collection and article preparation. 